\title{
Pengaruh Modal Sosial Terhadap Penciptaan Usaha Baru Yang Dimediasi Oleh Efikasi Diri Pada Mahasiswa Jurusan Manajemen Fakultas Ekonomi Dan Bisnis Universitas Tarumanagara
}

\author{
Jordrius Pangestu dan Andi Wijaya \\ Program Studi S1 Manajemen Fakultas Ekonomi Universitas Tarumanagara, Jakarta \\ Email: jordrius.115160207@stu.untar.ac.id
}

\begin{abstract}
This study was conducted with the aim of finding out whether there is an effect of social capital on the new venture creation with self-efficacy as a mediating variable. The subjects of this study were 40 students majoring in management at the Tarumanagara University Faculty of Economics and Business who have a private business with a business age under 5 years. The sampling method is done by purposive sampling method. This study uses data analysis with the Partial Least Square (PLS) approach in the form of the Smart-PLS application version 3.0. The findings show that social capital does not significantly affect new venture creation. However, there is an indirect effect of social capital on new venture creation through self-efficacy as a mediating variable.
\end{abstract}

Keywords: Social Capital, New Venture Creation, Self-Efficacy, Cognitive Factors .

Abstrak: Penelitian ini dilakukan dengan tujuan untuk mengetahui apakah terdapat pengaruh modal sosial terhadap penciptaan usaha baru dengan efikasi diri sebagai variabel mediasi. Subyek penelitian ini adalah 40 mahasiswa jurusan manajemen Fakultas Ekonomi dan Bisnis Universitas Tarumanagara yang memiliki bisnis pribadi dengan usia bisnis dibawah 5 tahun. Metode pengambilan sampel dilakukan dengan metode purposive sampling. Penelitian ini menggunakan analisis data dengan pendekatan Partial Least Square (PLS) berupa aplikasi Smart-PLS versi 3.0. Temuan menunjukkan bahwa modal sosial tidak berpengaruh secara signifikan terhadap penciptaan usaha baru. Namun, terdapat pengaruh tidak langsung modal sosial terhadap penciptaan usaha baru lewat efikasi diri sebagai variabel mediasi.

Kata Kunci: Modal Sosial, Penciptaan Usaha Baru, Efikasi Diri, Faktor Kognitif.

\section{LATAR BELAKANG}

Telah diakui secara luas bahwa kewirausahaan adalah pendorong utama pertumbuhan ekonomi dan penciptaan lapangan pekerjaan dalam suatu negara (Bates dan Dunham, 1993; Oviatt dan McDougall, 1997; Thurik dan Wennekers, 2004). Peran kewirausahaan bagi pertumbuhan ekonomi tidak hanya sekedar meningkatkan output dan pendapatan per kapita, namun juga melibatkan pengenalan atau penerapan perubahan dalam struktur bisnis maupun dalam masyarakat (Hisrich et al., 2008). Selain itu, kewirausahaan juga turut ambil bagian dalam membuka lapangan pekerjaan. Hal inilah 
yang membuat keberadaan kewirausahaan di suatu negara sangatlah penting, terutama di negara Indonesia yang memiliki angka pengangguran yang cukup tinggi.

Kewiraushaan mulai digemari oleh masyarakat Indonesia. Hal ini dapat dilihat dari meningkatnya persentase wirausaha di Indonesia. Berdasarkan informasi dari Kominfo, Kementerian Koperasi dan UKM melansir data olahan BPS dan menyimpulkan bahwa ada pertambahan tingkat persentase wirausaha dari yang sebelumnya $1,6 \%$ pada akhir tahun 2016 meningkat menjadi 3,1\% dari populasi atau sekitar 8,06 juta jiwa pada akhir tahun 2017. Angka tersebut menggembirakan karena telah menembus batas psikologis $2 \%$. Meskipun demikian, tingkat persentase wirausaha di Indonesia tersebut masih di bawah beberapa negara di ASEAN seperti singapura, Malaysia, Thailand, dan Vietnam.

Rendahnya tingkat prsentase wirausaha di Indonesia dibandingkan dengan Negara-negara di ASEAN perlu mendapatkan perhatian penting. Padahal, mereka memainkan peran penting dalam penciptaan usaha baru (Ozdemir et al., 2014; Baron, 2007). Dengan terciptanya usaha baru, mereka dapat membuka lapangan pekerjaan yang nantinya dapat mengurangi masalah pengangguran di Indonesia. Proses penciptaan usaha baru tidaklah mudah. Banyak sekali faktor yang mempengaruhi proses penciptaan usaha baru. Faktor-faktor tersebut bisa berasal dari luar diri seseorang (eksternal) maupun dalam diri seseorang. Faktor-faktor tersebut saling berkaitan dan bersama-sama membentuk perilaku seseorang. Perilaku tersebut akan menentukan seseorang dalam menumbuhkan minat mereka dan kemudian dapat merealisasikan ide-ide mereka menjadi suatu usaha baru.

Modal sosial juga turut mempengaruhi keputusan penciptaan usaha baru (Baron dan Markman, 2003; Liao dan Welsch, 2005; De Carolis dan Saparito, 2006). Penciptaan usaha baru tidak dapat dibuat sendiri sendiri, tapi juga melibatkan berbagai pihak. Wirausaha mendapat dukungan, pengetahuan, gagasan, dan sebagainya melalui jejaring sosial mereka. Penciptaan usaha baru membutuhkan banyak dorongan dari teman dan keluarga wirausaha tersebut sehingga dapat membuat mereka percaya diri secara kognitif dalam membentuk usaha baru (Davidsson dan Honig, 2003). Biasanya, pengusaha memiliki keterampilan dalam mengembangkan hubungan serta mendapatkan dukungan dan pengetahuan dari berbagai macam orang melalui jejaring sosial (Puhakka, 2006).

Sampai saat ini, peneliti telah menggunakan tiga bidang pendekatan seperti ekonomi (pendekatan berbasis hasil), psikologi (pendekatan sifat), dan strategi (pendekatan kinerja usaha) untuk memahami hubungan antara penciptaan usaha baru dan wirausaha (Mitchell et al., 2002). Sayangnya, peneliti yang telah menggunakan bidangbidang tersebut belum mampu menemukan karakteristik unik bagi pengusaha (Mitchell et al., 2002). Oleh karena itu, peneliti beralih untuk mempelajari perilaku individu sebagai hasil dari interaksi antara individu dengan situasi yang dialaminya. Pendekatan yang digunakan yaitu pendekatan kognitif. Pendekatan kognitif menekankan bagaimana seseorang berpikir, berkata dan berperilaku yang dipengaruhi oleh proses mental, seperti motivasi, persepsi, dan/atau sikap (Krueger Jr, 2003) dimana mereka memperoleh, menyimpan, mengubah, dan menggunakan informasi untuk membuat penilaian, atau keputusan (Mitchell et al., 2002). Salah satu faktor kognitif yang seringkali diteliti dalam konteks kewirausahaan yaitu efikasi diri. 
Konsep efikasi diri pertama kali dikemukakan oleh Albert bandura (1986) dan menjadi salah satu faktor kognitif yang mempengaruhi penciptaan usaha baru. Efikasi diri mengacu pada kepercayaan kemampuan seseorang. Dengan kata lain, efikasi diri adalah persepsi tentang diri sendiri apakah mereka memiliki kemampuan yang dibutuhkan untuk mengubah keterampilan mereka dalam mencapai hasil yang diinginkan (Wood \& Bandura, 1989). Kemampuan wirausaha dalam mengidentifikasi peluang, memasarkan produk mereka, memperoleh dana yang dibutuhkan merupakan penentu dalam memulai usaha baru. Jika seorang individu memiliki keyakinan bahwa ia memiliki keterampilan tersebut (kemampuan untuk mengha dapi tantangan dan hambatan yang terkait dengan penciptaan usaha baru) maka ia akan memulai usaha baru (Wood \& Bandura, 1989; Krueger et al., 2000; Wilson dkk., 2009). Jika tidak memiliki keyakinan tersebut maka ia akan menghindari untuk memulai usaha baru.

Oleh karena itu, penelitian ini dilakukan dengan dua tujuan, yang pertama yaitu untuk meneliti apa pengaruh modal sosial terhadap penciptaan usaha baru. Kedua, yaitu untuk meneliti pengaruh modal sosial terhadap penciptaan usaha baru melalui faktor kognitif yang berupa efikasi diri. Metode, hasil penelitian, diskusi, dan penelitian lebih lanjut akan dibahas pada bagian selanjutnya.

\section{KAJIAN TEORI}

Modal sosial merupakan jejaring hubungan pribadi yang kuat yang memberikan dasar kepercayaan, kerja sama dan tindakan kolektif (Coleman, 1988). Beberapa contoh jejaring sosial (Halpern, 2005) meliputi: pergi bekerja dan bergaul dengan rekan kerja; menjadi anggota serikat pekerja atau profesional di luar konteks pekerjaan; pada waktu senggang, kita dapat bermain olahraga dengan kelompok atau klub tertentu; dan dalam kehidupan pribadi kita, kita adalah bagian dari keluarga, lingkungan, dan mungkin juga komunitas agama atau etnis.

Menurut Nahapiet dan Ghoshal (1998) modal sosial dibedakan atas tiga aspek: struktural, relasional dan kognitif. Modal sosial struktural menggambarkan konfigurasi hubungan antara orang dan unit, sementara modal relasional menggambarkan hubungan pribadi yang telah dikembangkan orang melalui periode interaksi. Faktor kunci dalam jenis modal ini adalah kepercayaan dan kepercayaan berdasarkan riwayat pertukaran yang sukses. Modal sosial dibangun oleh kepercayaan-kepercayaan antar individu. Rasa saling percaya dibentuk dalam waktu yang tidak sebentar serta memerlukan prosesproses sosial yang berliku (Fukuyama, 2001).

Seorang wirausaha memanfaatkan ikatan sosial dan interaksi yang mereka miliki (dimensi struktural) untuk membentuk norma dan jejaring mereka (dimensi kognitif) yang digunakan untuk mengembangkan kepercayaan serta akses mereka ke berbagai dukungan sosial (dimensi relasional) dalam suatu proses penciptaan usaha baru (Liao \& Welsch, 2005). Namun studi lain mengatakan bawha modal sosial tidak selalu memfasilitasi proses penciptaan usaha baru secara universal. Modal sosial yang tertanam dalam jaringan terbukti membentuk karakteristik kognitif seorang wirausaha, sehingga memengaruhi kemajuan mereka dalam menciptakan usaha baru (De Carolis et al., 2009). Dengan memiliki banyak koneksi akan membuka peluang dalam penciptaan usaha baru. Namun, diperlukan adanya suatu perangkat karakteristik kognitif dari dalam diri individu untuk menuntunnya kepada penciptaan usaha baru. Meskipun, modal sosial menyediakan 
ide-ide, informasi, dukungan dalam mengevaluasi pilihan alternatif, membantu membuat keputusan, dan persepsi kepada peluang baru, tetapi hal tersebut tidak berlaku sama kepada semua pihak. (Kannadhasan et al, 2018).

Salah satu teori yang dapat menjelaskan perilaku kognitif seseorang adalah Teori Kognitif Sosial (Social Cognitive Theory). Teori ini menjelaskan bagaimana seseorang memperoleh kompetensi kognitif, sosial, emosional, perilaku, dan juga bagaimana mereka memotivasi dirinya dan mengatur perilaku mereka serta menciptakan sistem sosial yang mengatur dan menyusun kehidupan mereka. Salah satu faktor kognitif yang digunakan untuk menjelaskan pengaruh modal sosial terhdap penciptaan usaha baru adalah efikasi diri.

Efikasi diri mengacu pada kepercayaan individu akan kemampuannya untuk sukses dalam melakukan sesuatu (Bandura, 1986). Efikasi diri merupakan komponen dari karakteristik kognitif yang mempengaruhi kewirausahaan seseorang (Chen et al., 1998). Semakin tinggi tingkat efikasi diri seseorang semakin tinggi pula tingkat intensi kewirausahaan seseorang yang kemudian mendasari penciptaan usaha baru tersebut. Modal sosial berkaitan dengan efikasi diri lewat jejaring sosial yang dimiliki seseorang. Jejaring sosial menentukan perilaku kognitif seseorang. Seseorang yang memiliki jejaring sosial yang erat cenderung memiliki tingkat efikasi diri yang lebih tinggi dibandingkan yang tidak (Kannadhasan dkk., 2018).

Model penelitian ini dapat digambarkan sebagai berikut:

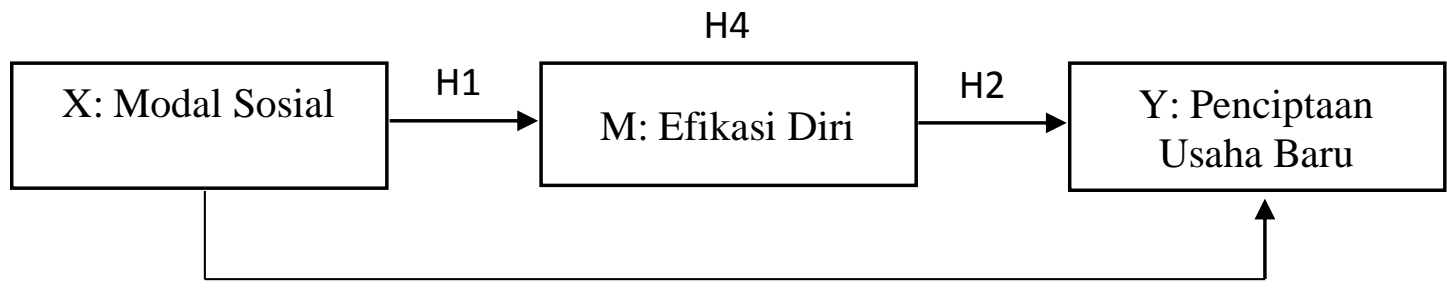

H3

Gambar 1. Model Penelitian berikut:

Berdasarkan model penelitian di atas, hipotesis dari penelitian ini adalah sebagai

H1 : Modal sosial memilik pengaruh terhadap efikasi diri secara positif dan signifikan.

H2 : Efikasi diri memiliki pengaruh terhadap penciptaan usaha baru secara positif dan signifikan.

H3 : Modal Sosial memiliki pengaruh terhadap penciptaan usaha baru secara positif dan signifikan.

H4 : Efikasi diri dapat memediasi kaitan antara modal sosial dan penciptaan usaha baru secara positif dan signifikan. 


\section{METODOLOGI}

Data diambil dari mahasiswa jurusan manajemen Fakultas Ekonomi dan Bisnis Universitas Tarumanagara yang berjumlah 40 orang. Teknik pemilihan teknik pemilihan sampel yang digunakan dalam penelitian ini adalah teknik teknik pengambilan sampel bertujuan (purposive sampling) dimana sampel harus memiliki bisnis pribadi dengan usia bisnis dibawah 5 tahun sebagai pertimbangan pemilihan sampel. Instrumen yang digunakan adalah kuisioner baik secara langsung ataupun secara online menggunakan google form. Data diolah menggunakan metode Partial Least Square (PLS) dengan aplikasi Smart-PLS versi 3.0.

Penelitian ini menggunakan tiga variabel yaitu, variabel modal sosial, efikasi diri, dan penciptaan usaha baru. Modal sosial memiliki tiga dimensi, yaitu dimensi struktural, relasional, dan kognitif. Dimensi struktural, relasional, dan kognitif masing-masing memiliki 4, 3, dan 2 item yang diadaptasi dari Puhakka (2006). Efikasi diri memiliki 16 item yang dikembangkan oleh DeNoble et al. (1999). Penciptaan usaha baru memiliki 3 item yang diadaptasi oleh Keh et al. (2002). Semua konstuk diukur menggunakan skala Likert 5 poin.

\section{HASIL ANALISIS DATA}

Tabel 1. Tabel AVE

\begin{tabular}{|c|c|c|}
\hline Variabel & Nilai AVE & Keterangan \\
\hline Modal Sosial & 0,550 & Valid \\
\hline Efikasi Diri & 0,515 & Valid \\
\hline Penciptaan Usaha Baru & 0,698 & Valid \\
\hline
\end{tabular}

Uji validitas dilakukan dengan melihat nilai AVE. Apabila nilai AVE lebih besar atau sama dengan 0,5 (Hair et al., 2012) maka instrumen penelitian tersebut dapat dikatakan valid. Hasil pengujian menunjukkan bahwa semua item dalam penelitian ini memiliki nilai AVE lebih besar dari 0,5. Dengan demikian, semua item dalam penelitian ini adalah valid.

Tabel 2. Tabel Cronbach's Alpha

\begin{tabular}{|c|c|c|}
\hline Variabel & Nilai Cronbach's Alpha & Keterangan \\
\hline Modal Sosial & 0,881 & Reliabel \\
\hline Efikasi Diri & 0,912 & Reliabel \\
\hline Penciptaan Usaha Baru & 0,783 & Reliabel \\
\hline
\end{tabular}

Uji reliabilitas instrumen dalam PLS menggunakan Cronbach's Alpha dari blok indikator yang mengukur konstruknya. Suatu instrumen dikatakan reliabel jika nilai Cronbach's Alpha berada di atas tingkat ambang 0,7 (Nunnally, 1967). Hasil Pengujian 
menunjukkan bahwa semua item dalam penelitian ini memiliki nilai Cronbach's Alpha lebih besar dari 0,7 .

Tabel 3. Tabel $R$ Square

\begin{tabular}{|c|c|}
\hline & $\mathbf{R}^{\mathbf{2}}$ \\
\hline Efikasi Diri & 0,554 \\
\hline Penciptaan Usaha Baru & 0,304 \\
\hline
\end{tabular}

Uji koefisien determinasi dilakukan dengan melihat nilai $R$ Square. Nilai $R$ square digunakan untuk menilai variasi pengaruh variabel independen terhadap variabel dependen. Hasil pengujian menunjukkan bahwa nilai $R$ Square untuk efikasi diri adalah 0,554 dan untuk penciptaan usaha baru adalah 0,304.

Tabel 4. Tabel Uji Hipotesis

\begin{tabular}{|c|c|c|}
\hline Variabel & T-Statistik & P Values \\
\hline Modal Sosial $\rightarrow$ Efikasi Diri & 15,566 & 0,000 \\
\hline Efikasi Diri $\rightarrow$ Penciptaan Usaha Baru & 2,188 & 0,029 \\
\hline Modal Sosial $\rightarrow$ Penciptaan Usaha Baru & 0,189 & 0,850 \\
\hline
\end{tabular}

Pengujian hipotesis dilakukan dengan menggunakan metode bootstrapping. Pengujian hipotesis dilakukan dengan membandingkan nilai $p$-value dengan tingkat kepercayaan $(\alpha)$ sebesar 0,05 . Koefisien regresi adalah signifikan apabila nilai $p$-value < 0,05 (Haryono, 2017).

Hasil pengujian H1 untuk menguji pengaruh modal sosial terhadap efikasi diri menunjukkan nilai $p$-value sebesar 0,000. Dengan demikian, dapat disimpulkan bahwa H1 tidak ditolak.

Hasil pengujian $\mathrm{H} 2$ untuk menguji pengaruh efikasi diri terhadap penciptaan usaha baru menunjukkan nilai p-value sebesar 0,029. Dengan demikian, dapat disimpulkan bahwa $\mathrm{H} 2$ tidak ditolak.

Hasil pengujian $\mathrm{H} 3$ untuk menguji pengaruh efikasi diri terhadap niat berwirausaha menunjukkan nilai p-value sebesar 0,850. Dengan demikian, dapat disimpulkan bahwa $\mathrm{H} 3$ ditolak. 
Pangestu dan Wijaya: Pengaruh Modal Sosial Terhadap Penciptaan Usaha Baru...

Tabel 5. Tabel Uji Mediasi

\begin{tabular}{|c|c|}
\hline Variabel & P Values \\
\hline Modal Sosial $\rightarrow$ Efikasi Diri $\rightarrow$ Penciptaan Usaha Baru & 0,037 \\
\hline
\end{tabular}

Pengujian mediasi dilakukan untuk mengetahui apakah suatu variabel ikut mempengaruhi kaitan antara variabel independen dengan variabel dependen. Pengujian mediasi dalam PLS dapat dilihat nilai $p$-value pada tabel specific indirect effect. Hasil pengujian $\mathrm{H} 4$ untuk menguji mediasi menunjukkan nilai $p$-value sebesar 0,037. Dengan demikian, dapat disimpulkan bahwa $\mathrm{H} 4$ tidak ditolak.

\section{DISKUSI}

Hasil analisis koefisien determinasi efikasi diri menunjukkan nilai $\mathrm{R}^{2}$ sebesar 0,554 . Artinya, variabel efikasi diri dapat dijelaskan oleh variabel modal sosial sebesar 55,4 persen sementara sisanya sebesar 44,6 persen dijelaskan oleh variabel lain yang tidak terdapat dalam penelitian ini.

Sementara itu, hasil analisis koefisien determinasi penciptaan usaha baru menunjukkan nilai $\mathrm{R}^{2}$ sebesar 0,304. Artinya, variabel penciptaan usaha baru dapat dijelaskan oleh variabel modal sosial dan efikasi diri sebesar 30,4 persen sementara sisanya sebesar 69,6 persen dijelaskan oleh variabel lain yang tidak terdapat dalam penelitian ini.

Hasil pengujian hipotesis menunjukkan bahwa H1 tidak ditolak. Sehingga, dapat disimpulkan bahwa terdapat pengaruh modal sosial terhadap efikasi diri. Kannadhasan dkk. (2018) menjelaskan bahwa jejaring sosial menentukan perilaku kognitif seseorang. Seseorang yang memiliki jejaring sosial yang erat cenderung memiliki tingkat efikasi diri yang lebih tinggi dibandingkan yang tidak.

Hasil pengujian hipotesis menunjukkan bahwa $\mathrm{H} 2$ tidak ditolak. Sehingga, dapat disimpulkan bahwa terdapat pengaruh efikasi diri terhadap penciptaan usaha baru. Chen dkk. (1998) menjeaskan bahwa efikasi diri merupakan komponen dari karakteristik kognitif yang mempengaruhi kewirausahaan seseorang. Semakin tinggi tingkat efikasi diri seseorang semakin tinggi pula tingkat intensi kewirausahaan seseorang yang kemudian mendasari penciptaan usaha baru tersebut.

Hasil pengujian hipotesis menunjukkan bahwa H3 ditolak. Sehingga, dapat disimpulkan bahwa tidak terdapat pengaruh modal sosial terhadap penciptaan usaha baru. Kannadhasan dkk. (2018) menjelaskan bahwa dengan memiliki banyak koneksi akan membuka peluang dalam penciptaan usaha baru. Namun, diperlukan adanya suatu perangkat karakteristik kognitif dari dalam diri individu untuk menuntunnya kepada penciptaan usaha baru. Meskipun, modal sosial menyediakan ide-ide, informasi, dukungan dalam mengevaluasi pilihan alternatif, membantu membuat keputusan, dan persepsi kepada peluang baru, tetapi hal tersebut tidak berlaku sama kepada semua pihak.

Hasil pengujian mediasi menunjukkan bahwa H4 tidak ditolak. Sehingga, dapat disimpulkan bahwa efikasi diri dapat memediasi kaitan antara modal sosial dan 
penciptaan usaha baru. Kannadhasan dkk. (2018) menjelaskan bahwa seorang individu yang memiliki seperangkat karakteristik kognitif yang bersama sebagai kelompok, memiliki tingkat kesadaran yang lebih tinggi. Dengan demikian, hal ini mengarah pada lebih banyak peluang. Akibatnya, wirausaha yang memiliki tingkat efikasi diri yang lebih tinggi, memiliki tingkat yang lebih tinggi dalam merealisasikan peluang menjadi kenyataan.

\section{PENUTUP}

Berdasarkan hasil pengujian tersebut, maka dapat disimpulkan bahwa tidak terdapat pengaruh modal sosial terhadap penciptaan usaha baru, namun terdapat pengaruh tidak langsung modal sosial terhdap penciptaan usaha baru melalui efikasi diri. Selain itu, terdapat pengaruh modal sosial terhadap efikasi diri, terdapat pengaruh efikasi diri terhadap penciptaan usaha baru, serta efikasi diri memediasi kaitan antara modal sosial dan penciptaan usaha baru.

Keterbatasan dalam penelitian ini adalah waktu yang tersedia dalam penelitian ini terbatas sehingga penelitian ini hanya dilakukan pada ruang lingkup yang sempit, yaitu Jurusan Manajemen Fakultas Ekonomi dan Bisnis Universitas Tarumanagara. Selain itu, faktor-faktor yang mempengaruhi penciptaan usaha baru hanya terbatas pada satu variabel yaitu modal sosial, sedangkan masih banyak variabel lain yang mempengaruhi penciptaan usaha baru.

Berdasarkan hasil penelitian ini, maka beberapa saran yang dapat diberikan oleh peneliti adalah sebagai berikut: (1) Bagi Universitas, mahasiswa perlu diajarkan mengenai pemahaman dalam meningkatkan jaringan sosial seperti cara berhubungan dengan investor, supplier, konsumen, ataupun stakeholder. Selain itu, universitas dapat mengembangkan inkubator bisnis untuk membina mahasiswa sehingga dapat mengembangkan usahanya terutama bagi mahasiswa yang baru menciptakan usahanya. (2) Bagi wirausaha yang baru menciptakan usahanya diharapkan juga dapat meningkatkan modal sosial yang dimilikinya. Modal sosial inilah yang akan membuka akses wirausaha kepada sumberdaya lainnya yang dapat membantu wirausaha tersebut dalam mengembangkan usahanya. (3) Bagi penelitian selanjutnya diharapkan untuk menambah variabel-variabel lain yang turut mempengaruhi penciptaan usaha baru seperti women empowerment, environmental uncertainty, opportunity recognition, dan lain-lain. Selain itu, penelitian selanjutnya juga dapat menggunakan faktor kognitif lainnya yang dapat memediasi kaitan antara modal sosial dengan penciptaan usaha baru seperti risk perception, risk propensity, illusion of control, overconfidence, dan fear of failure untuk memperdalam dan melengkapi hasil penelitian ini.

\section{DAFTAR PUSTAKA}

Bandura, A. (1986). Social foundations of thought and action: A social cognitive theory. Engle wood Cliffs, NJ: Prentice-Hall.

Baron, R.A. \& Markman, G.D. (2003). “Beyond social capital: the role of entrepreneur's social competence in their fimamcial success", Journal of Business Venturing, Vol. 18 No. 1, pp. 41-60. 
(2007). "Behavioral and cognitive factors in entrepreneurship: entrepreneurs as the active element in new venture creation", Strategic Entrepreneurship Journal, Vol. 1 Nos 1-2, pp. 167-182.

Bates, T. \& Dunham, C.R. (1993). "Asian-American success in self-employment", Economic Development Quarterly, Vol. 7 No. 2, pp. 199-214.

Chen, C.C., Greene, P.G. \& Crick, A. (1998). "Does entrepreneurial self-efficacy distinguish entrepreneurs from managers?" Journal of Business Venturing, Vol. 13 No.4, pp. 295-316.

Coleman JS. (1988). Social capital in the creation of human capital. American Journal of Sociology 94: 95-120.

Davidsson, P. \& Honig, B. (2003), "The role of social and human capital among nascent entrepreneurs", Journal of Business Venturing, Vol. 18 No. 3, pp. 301-331.

De Carolis, D.M. \& Saparito P. (2006). "Social capital, cognition, and entrepreneurial opportunities: a theoretical framework", Entrepreneurship Theory and Practice, Vol. 30 No. 1 pp. 41-56.

, Litzky, B.E., \& Eddleston, K.A. (2009), "Why networks enhance the progress of new venture creation: the influence of social capital and cognition", Entrepreneurship Theory and Practice, Vol. 33 No. 2, pp. 527-545.

De Noble, A.F., Jung, D. \& Ehrlich, S.B. (1999), "Entrepreneurial self-efficacy: the development of a measure and its relationship to entrepreneurial action", Frontiers of Entrepreneurship Research, Vol. 1999 No.1, pp. 73-87.

Fukuyama, F. (2001). Social capital, civil society and development. Third World Quarterly, 22(1), 7-20. doi:http://dx.doi.org/10.1080/713701144

Hair, J. F., Sarstedt, M., Ringle, C.M., \& Mena, J.A. (2012), “An assessment of the use of partial least squares structural equation modeling in marketing research", Journal of the Academy of Marketing Science, Vol. 40 No. 3, pp. 414-433.

Halpern, D. (2005). Social Capital. Cambridge: Polity Press

Haryono, S. (2017). Metode SEM untuk Penelitian Manajemen AMOS LISREL PLS. Jakarta: Luxima Metro Media.

Hisrich, R.D, Peters, M.P., \& Shepherd, D.A. (2008). Entrepreneurship: Mc Graw Hill International Edition.

Kannadhasan, M., Charan, P., Singh, P., \& N, S. (2018). Relationships among social capital, self-efficacy, and new venture creations. Management Decision, 56(1), 204-218.

Kementrian Komunikasi dan Informatika Republik Indonesia. (2017). Peluang Besar Jadi Pengusaha Di Era Digital. Diambil kembali dari Kementrian Komunikasi dan Informatika Republik Indonesia: https://kominfo.go.id/content/detail/9503/peluang-besar-jadi-pengusaha-di-eradigital/0/berita tanggal 2 September 2019.

Krueger, N.F. Jr. (2003). "The cognitive psychology of entreprenurship", Handbook of Entrepreneurship Research, Springer, Boston, MA, pp. 105-140.

Liao, J. \& Welsch, H. (2005), "Roles of social capital in venture creation: key dimension and research implication", Journal of Small Business Management, Vol. 43 No.4, pp. 345-362.

Mitchell, R.K., Busenitz, L., Lant, T., McDougall, P.P., Morse, E.A. \& Smith, J.B. (2002). "Toward a theory of entrepreneurial cognition: rethinking the people of side 
of entrepreneurship research", Entrepreneurship Theory and Practice, Vol. 27 No. 2, pp. 93-140.

Nahapiet, J., \& Ghoshal, S. (1998). Social capital, intellectual capital, and the organizational advantage. Academy of Management.the Academy of Management Review, 23(2), 242-266.

Nunnally, J.C. (1967), Psychometric Theory, McGraw-Hill, New York, NY.

Oviatt, B.M. \& McDougall, P.P. (1997), "Challenges for internationalization process theory: the case of international new ventures", Management International Review, Vol. 37 No. 1, pp. 85-99.

Ozdemir, S.Z., Moran, P., Zhong, X. \& Bliemel, M.J. (2014). "Reaching and acquiring valuable resources: the entrepreneur's use of brokerage, cohesion, and embeddedness", Entrepreneurship Theory and Practice, Vol. 40 No. 1, pp. 49-79.

Puhakka, V. (2006), "Effects of social capital on the opportunity recognition process", Journal of Enterprising Culture, Vol. 14 No. 02, pp. 105-124.

Thurik, R. \& Wennekers, S. (2004), "Entrepreneurship, small business and economic growth", Journal of Small Business and Enterprise Development, Vol. 11 No. 1, pp. 140-149.

Wilson, F., Kickul, J., Marlino, D., Barbosa, S.D. \& Griffiths, M.D. (2009). “An analysis of the role of gender and self-efficacy in developing female entrepreneurial interest and behavior", Journal of Development Entreprneurship, Vol. 14 No. 2, pp. 105119.

Wood, R. \& Bandura, A. (1989). "Social cognitive theory of organizational management”, Academy of Management Review, Vol. 14 No. 3, pp. 361-384. 